\title{
Karol Chylak
}

(Społeczna Akademia Nauk w Łodzi)

\section{The Church Rates (Contributions) in the Parishes in the Second Republic of Poland}

The Church rate, church fee, church contribution. In the period of the Second Republic of Poland both, state and ecclesiastical authorities used these terms in order to determine financial weights voluntarily adopted by parish institutions, although obligatorily paid by the faithful of the Roman Catholic Church. These notions were used interchangeably though within years a tendency to more strict approach could be seen. The Ministry of Treasury opposed the usage of the "tax" term indicating necessity of being more precise by consequently using the "church contribution" term. As we can read in one of the letters of the Ministry of Treasury: The church contribution can not be treated as "sui generis" tax for the benefit of this kind of institution ${ }^{1}$. Hence, such statement was quoted in the act issued in 1932 that regulated the problem ${ }^{2}$. Nevertheless, it did not change the fact that, particularly in the former Prussian annexation, it was preferred to use the term "tax" rather than "contribution".

Church taxes issue has always constituted one of the major problems in relationship between the state and the Church in the II Republic of Poland. It has been crucial for operating of the particular parishes in the local environment as well. It constituted an element of negotiations of concordat between Poland and the Holy Sea. This study is an attempt to familiarize with the issue, which has been, ignored in the literature and, in fact, it has never been studied and described.

1 Original text: Składka kościelna, jako świadczenie przymusowe ludności nie może być uznana $z a$ „sui generis” podatek na rzecz tego rodzaju instytucji. The Central Archives of Modern Records (Archiwum Akt Nowych, AAN), Ministry of Religious Affairs and Public Education (Ministerstwo Wyznań Religijnych i Oświecenia Publicznego, MWRiOP), sygn. 893, Official letter from the Ministry of Treasury (Ministerstwo Skarbu) to the MWRiOP, 03.14.1927, 275.

Dziennik Ustaw Rzeczypospolitej Polskiej (DURP) 1932, no. 35, pos. 358. 


\section{Introduction of taxes in Poland}

Traditionally, the most commonly known and applicable tax in Poland was a tithe, which rose along with organization of the Church. In accordance with the Polish practice, the most dominating form of it was a sheaves tithe although it was possible that in the future the other forms would arise. That tax, so inconvenient for the payer, was not convenient for the beneficiary either. Current development in Poland did not seem to be impressive, so were not the related revenues. In the nineteenth century the contemporary leaders of Poland undertook the action aiming at liquidation of such archaic tax. The first to have completed the project were Austrians, in 1848. Afterwards, not long after the Austrians, the Russians (1864) and the Prussians (1865) ${ }^{3}$ also struggled to eliminate that form of tax.

Salary reforms, together with the regulations regarding organizational structure of the parishes, enabled all of them to impose another kinds of taxes in the nineteenths century. That time competences were given to the units managing the parishes the i.e. Parish the Councils and Church Supervisions. While in each annexation the situation was different, the aim of the tax was - more or less - the same.

In the Polish Kingdom mandatory charges for the benefit of the Church were introduced in $1817^{4}$. Generally, they concerned obligation to finance both construction and maintenance of the churches, other parish buildings and cemeteries, by parishioners. Actually, those services took on a personal character. Soon, on 3 January 1818, the viceroy developed the aforementioned king's decision introducing division of costs applicable to "buying materials and payment to the craftsmen" and to "import materials and manual help in the factory". The first ones were applicable to all owners and perpetual usufructs of the properties inhabited by the Catholics, regardless of their religious denomination. The second ones were applicable to the faithful of the Roman Catholic Church, "peasants on the land who make socage or pay a rent", and to the workmen. An important change was implemented by the resolution of the viceroy of the Polish Kingdom - by replacing the personal character of the charge with a tangible one applied to real estates (provided that they were inhabited by the Catholics) 5 .

3 Tadeusz Czacki, O dziesięcinach w powszechności, a szczegolniey w Polszcze i Litwie (Warszawa: Druk XX Pijarów, 1801), 3-79; Jan Wincenty Bandtkie Stężyński, Prawo prywatne polskie (Warszawa: Drukarnia Banku Polskiego, 1851), 309-325; Władysław Abraham, „O powstaniu dziesięciny swobodnej. Studium z dziejów prawa kościelnego w Polsce”, Biblioteka Warszawska 2 (1891): 146-180; Adolf Szelążek, „Memorjał w sprawie majątków kościelnych w Królestwie Polskim zabranych na mocy ukazów 1864 i 1865 r." (Płock: Drukania „Kurjera Płockiego” i „Mazura” (1917), 8-9, 29-30.

4 Dziennik Praw Królestwa Polskiego (DPKP) 1820, Vol. 6, 242-249.

AAN, MWRiOP, sygn. 892, Official letter from the Special Prosecutor's Office of the Republic of Poland (Prokuratoria Generalna Rzeczypospolitej Polskiej) to the MWRiOP, 12.31.1921, 22-24. 
In 1824, based on the legislation dated 1817, the Church Supervisions existing in the parishes were solely authorized to allocate taxes among the aforementioned parties ${ }^{6}$. In addition, public authorities and legal entities (i.e. railroads) were obliged to pay their contributions provided that they had goods on the territory of the particular parish.

Later, in 1863, that legislation was upheld 7 . However, enfranchisement reform forced the legislator to make a revision of law in that regard. Since July 1864 the ability to undertake any decision by the Church Supervision has depended on the Parishioners Assembly. Since than it has been stated that the Church Supervisions together with local government has not been authorized to impose any fees for the benefit of the Church without approval of the Parishioners Assembly, whereas the principle of division of the contribution itself has remained unchanged. The amendment was applicable only to the village parishes while in the cities the former legislation was sustained ${ }^{9}$. It might be stated, that important changes took place in years 1887 and 1889 when the Russian Senate, in a case stemming from the dispute between Jan Wilde and the Church Supervision from Byczyn, stated that the enfranchisement reform had abolished obligation of paying church fees by the owners and tenants other that Catholics ${ }^{10}$. However, that decision has been of no importance, from a formal perspective, as the decisions dated 1818 and 1824 could have been hanged only by the legislations signed by the monarch. Based on the above, the legislation remained valid. Yet, enfranchisement changed the situation completely. Becoming landowners, former peasants (obliged only to pay fees of the second category), became obligated to pay contributions indicated by the legislator as the fees of the first category. In case of parishes that consisted of cities and villages, contribution was divided into two in accordance with the rule of the "amount of households". In this regard, both cities and villages were obliged to pay fees, not their inhabitants. Within time, with reference to inhabitants of the villages, the quantity of land was a basis to calculate the amount of church fee. It was based on the abovementioned legislation dated 1864 in accordance with which the parishioner of the Roman Catholic Church, being authorized to take part in the Municipal Assembly, was obliged to pay church taxes ${ }^{11}$.

6 DPKP, 1824, Vol. 8, 321-322.

DPKP, 1863, Vol. 61, 137-139, 163-183.

8 Original text: Dozory kościelne i władze miejscowe nie mogq nakładać na parafian żadnych obowiązujących składek na kościół [...] bez zgodzenia się zgromadzenia samych parafian.

9 DPKP, 1864, Vol. 62, 283; AAN, MWRiOP, sygn. 893, Official letter from Special Prosecutor's Office of the Republic of Poland to MWRiOP, 12.20.1920, 49-54.

10 Zbiór Rozporządzeń Cesarstwa Rosyjskiego 1894, pos. 196; Karol Dębiński, Dozory kościelne rzymskokatolickie w Królestwie Polskiem (Warszawa: Drukarnia Polska, 1913), 26, 29-57.

11 AAN, MWRiOP, sygn. 893, Opinia Wydziału Wyznania rz-Katolickiego Departamentu Wyznań co do treści uchwał zebrania parafjalnego parafji Żytno, z dnia 9/6 1918 i 4/8 1918 roku, 36-37; Official letter from Special Prosecutor's Office of the Republic of Poland to The Civil Chancellery of the President of the Republic of Poland (Kancelaria Cywilna Prezydenta Rzeczypospolitej 
In the Prussian annexation church taxes in parishes were charged based on the legislation dated 14 July 1905 . This stated that church expenses would be covered by the taxes imposed on faithful, provided that the other sources were insufficient. State taxes and, above all, income tax (real estate tax or business tax) constituted basis to calculate these burdens ${ }^{12}$. While Church supervisions acted on the principles of the legislation dated 20 June 1870, decisions made by the Church Supervisions had to be approved by the representation of the church administrative district, bishop as well as the state authority ${ }^{13}$.

In fact, these taxes were not collected frequently. The relatively good material situation in the Prussian annexation sufficed to cover usual parish expenses. The tax was used in case of extraordinary expense; however, even in such situation, it could have been financed without additional taxes $(2 / 3$ of costs in cities and $1 / 3$ of such costs in villages) by using the patronage institution. The amount of the tax was not limited by any regulation. Nonetheless, local government was supposed to verify whether the church tax did not constitute unbearable burden for the community. Natural persons (members of catholic administrative districts) were obliged to take care of regulations regarding the enacted taxes ${ }^{14}$.

In former Austrian annexation, church taxes were based on the competitive act dated 15 July $1866^{15}$. That legislation was a consequence of changes that took place in the villages resulting from enfranchisement directives. Former practice regarding financing of both, renovation and construction investments usually based on church possessions as well as usual incomes of the Church, its parson, Religious Fund, the patron and, optionally, parishioners working for the benefit of the particular project. In fact, current expenses of the parish did not constitute an excessive burden neither to patron or to dominium nor to parishioners. However, in December 1860 the state authorities stated that parishioners, as well as church patron might be obliged to participate in sponsorship of the aforementioned expenses whereas the Religious Fund was supposed to be the ultimate source of financing. This decision, instead of making order, excluding the situation in Galicia, leaded to disorganization of the whole system. As summarized by Maurycy Kabat, a rapporteur of the competitive act project, proving a need of a new legislation in this regard: based on the aforementioned situation

Polskiej), 11.06.1929, 449-453; Władysław Grabski, Ciężary samorządu w Królestwie Polskiem (Warszawa: Skład Główny w Księgarni E. Wende i S-ka, 1908), 74-75.

12 Gesetz-Sammlung für die Königlichen Preussischen Staaten 1905, no. 28, 281-290.

13 Adolf Szelążek, Podstawy dotacji duchowieństwa katolickiego $w$ Polsce w okresie przedkonkordatowym (Toruń: Drukarnia Toruńska nr 4 Spółdzielni Wydawniczej „Wiedza”, 1947), 142-144.

14 AAN, MWRiOP, sygn. 93, Pokrywanie potrzeb kościelnych w katolickich gminach kościelnych w b. zaborze pruskim, 67-68; Szelążek, Podstawy dotacji, 143-144.

15 Jerzy Piwocki, „Zbiór ustaw i rozporządzeń administracyjnych” (Lwów: Piller, 1911), Vol. 3, 119-134. On the territory of Cieszyn Silesia, the directive dated 15 November 1863 was applicable. 
we could see that such an important matter, important for the whole country, was regulated by such an unstable directive ${ }^{16}$.

Competitive act constituted Parish Committees consisting of the parson - patron and the owners of the land located in the particular parish who, in case of lack of sufficient sources to cover construction, renovation or current parish operational expenses, might allocate the costs on parishioners having had real estate ${ }^{17}$. Furthermore, in 1896 a metter of church taxes was precisely determined. Since than, church taxes based on the fact of owning real estate in the particular parish. As a consequence, Catholics not resident in a given parish as well as legal persons (state treasury or administrative district), companies and associations were obliged to pay church taxes provided that they were payers of the real estate tax or the household tax. In case of enterprises that had their head office in the particular parish, the tax itself based on the fact of paying either salary tax or income tax ${ }^{18}$.

\section{An attempt to normalize the church tax issue in the Second Republic of Poland}

A process of structuring new relationship of the Church with the Polish government started after Poland's recovery of its independence. Church taxes appeared among many things that were discussed. Over one hundred years of slavery had resulted in completely different legal systems that were characteristic of each annexation, as well as different political cultures, had definitely negative impact on the discussion. Not only did it make difficult to reach an agreement with the representatives of the new state but also within the Church itself. Different legal status of the particular church institutions, various material situation as well as differentiated package of experiences has not been without influence on proposed solutions, attitude of clergy, possibilities of concessions, finally, influences in the decisive groups of the Polish authorities. In addition, differences regarding economical and social development between the particular districts as well as forms of relationship within the parish communities were of great importance.

16 Original text: $z$ powyższego przedłożenia stanu rzeczy widzimy na jak chwiejnych i niepewnych podstawach prawnych spoczywa dziś tak ważna dla kraju sprawa. Allegaty do Sprawozdań stenograficznych z trzeciej sesyi Sejmu Galicyjskiego z r. 1865-1866 (Allegat LXXXVI); Stenograficzne Sprawozdania z Trzeciej Sesyi Sejmu Krajowego Królestwa Galicyi i Lodomeryi wraz z Księstwem Krakowskiem w roku 1865-1866, 48, 86, 114, 1383, 1468, 1760-1764, 1778-1792, 1797-1836, 1839-1856.

17 Piwocki, „Zbiór ustaw”, 122-125.

18 Dziennik Ustaw i Rozporządzeń Krajowych dla Królestwa Galicyi i Lodomeryi wraz z Księstwem Krakowskiem 1896, no. 25. 
A matter of the church tax appeared while conducting negotiations regarding manors and salaries of clergy at the time prior to concordat. It was also connected with the postulate of liquidation of iura stolae. At the end of January 1922, shortly after inauguration of official negotiations regarding manor cases, a group of priests-deputies proposed that church institutions should be financed and maintained from the state budget. It was planned that finances would be gathered through implementation of special ubiquitous church $\operatorname{tax}^{19}$. Countersigning parties indicated that there were subsequent dangers for the position of Church regarding fees iura stolae that constituted one of the main sources of rising money necessary to maintain parishes in case of inflation. Lodzer bishop, Wincenty Tymieniecki, appealed that the case should be regulated immediately. He was under the pressure of developing Mariavite $\mathrm{Church}^{20}$. However, these proposals had not aroused an expected interest and, as a consequence, have not been discussed any more. In fact, both tax and iura stolae issues have usually been discussed separately. In addition, the idea of one, homogenous church tax has been abandoned in favor of the idea of organizing the already existing system of the parish church taxes.

A new chapter of relationship between the state and the Church was developed after countersigning concordat by the Holy Sea and the Polish government in 1925. Church taxes were not regulated directly in the aforementioned document however it did not neglect the matter completely. First of all, in the article XXIV it was guaranteed by the state that the Church had inviolability of law authority to any movable and immovable properties, capitals, incomes, and other laws ${ }^{21}$ that were owned by it. In addition, the state authority pledged to help by executing of church acts and directives (art. IV). Based on article XXIV all acts, directives, and decrees that were in the contrary to the agreement between Poland and the Holy Sea ${ }^{22}$.

Firstly, the idea of church taxes proceeded with the project of abolishing of legislation contradictory to the provisions of concordat. Under the pressure of Episcopate from former Congress Poland among many revoked legislations there were the directives regarding Church Supervisions ${ }^{23}$. As a consequence, a lack of clarity regarding actual cancellation of a law regarding Church Supervisions ${ }^{24}$

19 The Archdiocesan Archive of Gniezno (Archiwum Archidiecezji Gnieźnieńskiej, AAG), Primate's Documents (Akta Prymasowskie, AP) I, sygn. 104, Memorjał księży posłów, 01.27.1922, 68; Stanisław Adamski, „Reforma rolna a ziemie kościelne w ustawodawstwie, sejmie i stronnictwach", Wiadomości dla Duchowieństwa no. 10 (1923): 204-207.

20 The Diocesan Archive of Siedlce (Archiwum Diecezji Siedleckiej, ADS), Conferences (Konferencje), sygn. K III 35 VII, Protokół Konferencji Episkopatu Prowincji Warszawskiej, 02.08.1923, 4-6.

21 Original text: majątków ruchomych i nieruchomych, kapitałów, dochodów oraz innych praw.

22 DURP 1925, no. 72, pos. 501.

23 Okólnik Prezesa Rady Ministrów z dnia 26 VIII 2915 r., Monitor Polski no. 204 (1925): 1-2.

24 It concerned a formal way of abolishing law, i.e. a doubt whether in order to invalidate the aforementioned laws a decision made by the Prime Minister was sufficient, or if there was supposed to be used an usual legislative way (by Sejm). 
led to disorder in hitherto situation ${ }^{25}$. Since the beginning of 1925, Lodzer voivode advised electoral group in Wloclawek: [...] based on acts of Supervisions, provisions for the benefit of Churches from the parishioners were given. Suspension of their activities, before regulating the matters otherwise, would have counterproductive consequences, especially with reference to interests of parishes. In addition, it would stop many works that have already been started which have been financed from funds that had been raised based on resolutions regarding Parishioners Assembly [... $]^{26}$.

The aforementioned matter was discussed on 7 November 1925 during the meeting of the Committee of Bishops. Than, it was stated that standing members of Church Supervisions would retain their current functions and would constitute temporary Parish Council that would be dependent on ecclesiastical authority ${ }^{27}$. It has been of high importance to the possibility of conscription of church tax in the former Russian annexation. As it was stated in the documentation of Ministry of Religious Affairs and Public Education (MWRiOP): a state of ex lex took place. In some places churches and buildings deteriorate as people refused to give voluntary contribution, having been used to legislative division of fees and waiting for the formal "directive". On the contrary, in other parishes, local governors execute taking over of movables etc. although there is no legal base to submit such decisions ${ }^{28}$.

In former Prussian and Austrian annexation legal situation remained as it was although it had little in common with the contemporary tax system in Poland that constituted a basis to calculate contributions. However, at the beginning of 1926 Gniezno-Poznan archbishop issued directive that stated that so called parish representations would be liquidated and Parish Councils would replace Church Supervisions. That resolution was approved by the Poznan voivode that resulted in the legal situation completely different from the actual one ${ }^{29}$. The Kujawian

25 Original text: ...na podstawie uchwał Dozorów plyna świadczenia parafjan na rzecz kościołów. Wstrzymanie ich działalności przed unormowaniem tych spraw w inny sposób odbiłoby się fatalnie na interesach majątków parafji i spowodowałoby wstrzymanie wielu robót już rozpoczętych, na które płyna środki uchwalone przez zebrania parafialne... The Archdiocesan Archive of Warsaw (Archiwum Archidiecezjalne Warszawskie, AAW), Polish Episcopate (Episkopat Polski, EP), sygn. A II 1.1 (2642), Official letter from Diocesan Curia of Sandomierz (Kuria Diecezji Sandomierskiej) to Office of Polish Episcopate, 10.24.1925, 285; Official letter from Diocesan Curia of Sandomierz to MWRiOP, 11.07.1925, 286-287

26 AAW, EP, Official letter from Voivodeship Office in Lodz to Diocesan Curia of Wloclawek (Kuria Diecezji Włocławskiej), 09.08.1925, 251.

27 AAN, MWRiOP, sygn. 893, Pro memoria, 126.

28 Original text: ...zapanował po prostu stan ex lex. W jednych miejscowościach kościoły i budynki niszczeją, bo ludność przyzwyczajona do urzędowego rozkładania składek odmawia datków dobrowolnych i czeka na urzędowy "papier” - w innych starostowie i wójci wykonują egzekucyjne zajęcia ruchomości itp. mimo, że brak już obecnie podstawy prawnej do wydawania takich zarzadzeń. AAN, MWRiOP, sygn. 894, Pro domo, 162.

29 AAN, MWRiOP, sygn. 893, Official letter from MWRiOP to Voivodeship Office in Poznan, October 1926, 52-53; „Rady parafialne”, Miesięcznik Kościelny dla Archidiecezji Gnieźnieńskiej i Poznańskiej no. 1 (1926): 20. 
bishop Stanisław Zdzitowiecki proposed similar changes during the gathering of bishops in March 1926. Nonetheless, it was remarked that: Voluntary contributions would be highly expected ${ }^{30}$. In 1927 a group of parishioners in Bydgoszcz opposed the directive of the Parish Council that imposed church fee on faithful. Although rejected by the governor, the case has been transferred to the Supreme Administrative Court. In October 1928 the objection was legitimated and it was justified that changes made by the bishop together with the governor were illegal as the only way to proceed changes was through passing the directive by Parliament ${ }^{31}$.

A concordat and further activities initiated by church authorities in order to broaden their own autonomy, instead of leading to order, caused further complications in the matter. It required centralized actions, preparation of solution regulating the situation in the whole country, in a homogenous manner, adjusted to the existing legislation, not only with reference to relations between the state and the Church but also to the tax law.

During March 1925, a few weeks after the date of signing a concordat; information from MWRiOP was delivered to the office of the prime minister. It listed acts and directives necessary to be implemented in order to execute provisions of the concordat. Among many acts to be implemented immediately there was one regarding church tributes and one, act or - optionally - directive, regulating interference of church authorities in this regard. Tax issue has been connected with iura stolae. It was stated that, first of all, an agreement regarding salaries for church services must be reached. Furthermore, church taxes were supposed to be regulated. All fees were limited to construction and maintenance of church and the parson's real estates, churches as well as equipment and church facilities ${ }^{32}$.

Church fees issue was one of the easiest matters to be regulated among all cases that arose after the concordat. First of all, because a lack of a number of complicated aspects concerning secularization conducted by the authorities in the annexed territories. Stanisław Grabski, a director of MWRiOP, managed immediately, together with the Pontifical Commission, to prepare a project of act $^{33}$. A content of the act was prepared, as it seems, by Krakow bishop Adam Sapieha. It had already been discussed during concordat negotiations. In December 1924, during the extraordinary bishops' assembly, it was agreed that: the project

30 Original text: Byłoby bardzo pożadane, aby się ograniczać środkami dobrowolnymi. AAW, EP, sygn. A II 1.2 (1643), Protokół Zjazdu Biskupów Polski w dniach od 2 do 5 marca 1926, 12-13; Zarząd majątkiem kościelnym, 39-41.

31 AAN, MWRiOP, sygn. 893, Wyrok Najwyższego Trybunału Administracyjnego, 10.20.1928, $86-96$.

32 AAN, MWRiOP, sygn. 402, Wykaz projektów ustaw i rozporządzeń potrzebnych do wykonania konkordatu, 61, 67; Official letter from MWRiOP to the President of the Council of Ministers (Prezes Rady Ministrów), 04.30.1925, 78.

${ }_{33}$ ADS, Conferences, sygn. K III 35 IX, Konferencja prowincjonalna warszawska dnia 22 i 23 IV 1925, 16. 
of act placed by bishop from Krakow had to reviewed and, as far as it was possible, the most important aspects had to inputted into the scope of the concordat $t^{34}$. A concept, approved by both parties on 11 April 1926 assumed implementation of mandatory church taxes. That fee was applicable to parishioners; Catholics not residing in the particular parish, but with the real estate tax applicable there. In addition, it was applicable to a patron (provided that the function existed), legal persons - being obliged to pay real estate tax in the given parish (provided that the aims of the organization had not been visibly connected with another religious denomination) as well as entrepreneurs employing at least 100 Catholics $^{35}$. Funds raised that way were to cover investments and renovations of parish church buildings and parson's buildings, maintenance of church service as well as equipment and church facilities. Two organs managed the fund: Parish Division and Church Construction Council. The first one, leaded by the parson, had execution character whereas the second one was entitled to impose taxes. With reference to taxes up to $15 \%$ of the amount of direct state taxes there were no additional authorities' approvals required. However, above this level, up to $100 \%$, the decision had to be approved by Diocesan Council. Furthermore, over that limit (over $100 \%$ ) consent had to be given by the voivodeship parliament ${ }^{36}$.

Moreover, project of the act constituted diocesan construction fund; it was planned that funds would cover costs of construction and maintenance of cathedral churches. Likewise, two managing organs were appointed: Diocesan Division and Diocesan Council. Catholics - residents of the particular diocesan as well as not residing but paying real estate tax in the given diocesan could have been called for duty of paying church tax. The amount of tax could not have been higher than $5 \%$ of the amount of direct taxes ${ }^{37}$.

A key role in implementation of the fee mentioned above had Church Construction Council. Its members were parishioners whose term of office lasted six years. There were two kinds of members, the ones selected by Parishioners Assembly and the ones appointed by bishop. Members of the Council were supposed to be determined in executive order, as it was dependent on the amount of parishioners. A relation of members selected to the ones appointed was supposed to be as 1:1. However, it was acceptable that there would be preponderance of one group by no more then one member. These taxes were planned to be charged likewise to the procedure regarding tax municipal additions ${ }^{38}$.

34 Original text: złożony przez biskupa krakowskiego projekt ustawy [...] rozważyć, i o ile to będzie możliwe, zasadnicze linje wprowadzić do konkordatu. ADS, Concordate (Konkordat), sygn. K III 36 I, Protokół Nadzwyczajnego Zjazdu Biskupów Polski w Warszawie od dnia 4 do 6 grudnia 1924, 94.

35 Later, in amendments to the project, it was stated " $50 \%$ of workers".

36 AAN, MWRiOP, sygn. 893, Projekt ustawy o pokrywaniu kosztów stawiania i utrzymania katolickich budynków kościelnych i plebańskich tudzież sprawiania i utrzymania przyrządów i sprzętów kościelnych, 158-163.

37 Ibidem, 164-168.

38 Ibidem, 169; DURP 1923, no. 94, pos. 747. 
Further negotiations led to implementation of crucial changes in the project. Former version of the act was modified at the end of November 1926 during the meeting of Pontifical Commission with representatives of the government. In accordance with the new concept, called then an act on contributions for Catholic Church expenses, a group of aims which could have been covered from these finances (set up and extension of cemeteries, parish charity institutions) has been extended. Procedures regarding enacting and managing of the fund have been considerably changed, actually simplified. The Parish Council, half of which was selected by the Parishioners Assembly whereas the other half of its members was appointed by the bishop, made it. In addition, two kinds of taxes were maintained - for the benefit of parish and diocesan. Moreover, it was necessary to gain an approval of the voivode in case of collecting an amount exceeding $50 \%$ of the basic level ${ }^{39}$.

The case seemed to have been settled. However, on 7 January1927, during the interdivision meeting in the Presidium of the Council of Ministers, an already agreed proposal was rejected. As a consequence, the Ministry of Treasury was appointed to work on the new project ${ }^{40}$. The way of proceeding was changed. Until than, initiatives came from the Pontifical Commission. That time, however, the government decided to address the Church with their own proposal. During discussion on the project prepared by the Ministry of Treasury they decided to exclude territory of Silesian Voivodeship ${ }^{41}$. The Ministry, led by Gabriel Czechowicz, criticized the provisions of the project proposed by representatives of both, the government and the Episcopate. First of all, the "tax" definition was questioned as it was expected to call it the "fee". The change was justified by the fact that fees could be charged to cover "general-state needs". Furthermore, stable benefits were questioned as it was stated that such contribution might be of non-recurring, extraordinary benefit. Moreover, they limited aims of the fund that was supposed to cover only investment expenses whereas maintenance of church services and current parish activity were supposed to be financed from other sources. Finally, they discussed the case of managing funds, which - as coming from mandatory contributions - should have been controlled by the public authorities. The aforementioned principles constituted basis of the new proposal. Additionally, the contribution could not exceed $10 \%$ of the calculation basis. Having achieved approval of MWRiOP, the contribution could be raised up to $25 \%$, on exceptional basis ${ }^{42}$.

39 Ibidem, 228-231; Projekt ustawy o składkach na pokrycie potrzeb Kościoła katolickiego, 213-216.

40 Ibidem, Official letter from Ministry of Interior (Ministerstwo Spraw Wewnętrznych, MSW) do MWRiOP, 01.13.1927, 237.

${ }_{41}$ Ibidem, Protokół konferencji Komisji rządowej z dnia 28 I 1927 r. w sprawie wykonania konkordatu, 265-267; Protokół konferencji Komisji rządowej z dnia 12 II 1927 r. w Prezydium Rady Ministrów, 268-269.

42 Ibidem, sygn. 893, Official letter from Ministry of Treasury to MWRiOP, 03.14.1927, 275-277; Projekt ustawy o składkach na pokrywanie potrzeb Kościoła katolickiego, 278-280. 
Proposals presented by the Ministry of Treasury brought up many objections of MWRiOP, which required that some of the provisions agreed upon together with the Pontifical Commission, should be maintained. However, the author of the project was adamant and, having had his attitude advocated by the other chefs of Ministries, managed to force his proposals ${ }^{43}$. The final concept, being in accordance with the project of the Ministry of Treasury, was prepared at the end of June $1927^{44}$.

Church's attitude regarding proposals presented by the government was critical. They advocated the project prepared in November 1926. On the other hand, they indicated a number of paragraphs that were not acceptable in the Pontifical Commission's opinion. First of all, they pointed out the need of direct contributions accepting non-recurrence of such form of financing both, parishes and diocesans as not sufficient. In addition, it was indicated that the authorization of state authorities was overextended in comparison to the Church. Furthermore, there was a critic with reference to limitation of a number of payers (including persons exempt from paying direct contributions), the amount of fees as well as the projects that could be financed. In general, bishops demanded that there should be more disambiguation in imposing fees as well as in managing the fund however the government's attitude was not flexible in this regard ${ }^{45}$. In September 1927 there was an attempt to work out a common attitude. Moreover, the negotiations seemed to have been fruitful. All parties managed to reach an agreement with reference to the Parish Council, a level of influence of the government on it as well as the payers' fees. In addition, the authorities pledged to verify their attitude in respect to casual fees, the amount of high prices, church services and sponsorship of diocese ${ }^{46}$.

Since December 1927 an activity of the Papal Commission has stopped and the bishop from Lutsk, Adolf Szelążek, has continued all its cases. That change was, as it seemed, initiated by Józef Piłsudski. It was mentioned by Franciszek Salezy Potocki, a chef of the Department of Denominations in MWRiOP: since December 1927 r., i.e. since time when Y.E. Przeździecki has introduced W.E. [A. Szelążek] in Belweder, as the only one having been authorized to negotiate... ${ }^{47}$ On 22 February 1929,

43 Ibidem, Official letter from MWRiOP to Ministry of Treasury, 04.23.1927, 290-294; Protokół konferencji Komisji Rządowej z dn. 4 maja 1927 r. w sprawie wykonania konkordatu, 321-322; Official letter from Ministry of Treasury to MWRiOP, 05.12.1927, 325-326.

${ }_{44}$ Ibidem, Projekt ustawy o składkach na pokrycie niektórych potrzeb Kościoła katolickiego, 06.04.1927, 331-335.

45 Ibidem, Uwagi Komisji papieskiej do projektu ustawy o składkach na pokrycie niektórych potrzeb Kościoła katolickiego w tekście ustalonym na konferencji międzyministerialnej w d. 4/6 1927, 327-330.

46 The Diocesan Archive of Lomza (Archiwum Diecezji Łomżyńskiej, ADŁ), Group of the New Documents (Zespół Akt Nowych, ZAN), sygn. 260, Protokół z konferencji w Warszawie, 09.14.1927, non-paginated.

47 Original text: od grudnia 1927 r., tj. od chwili, gdy J.E. ks. bp Przeździecki przedstawit W.E. [A. Szelążka] w Belwederze, jako jedynie upoważnionego do pertraktowania... AAN, MWRiOP, sygn. 894, Letter from F.S. Potocki to A. Szelążek (project), 11. 
after negotiations lasting almost two years and a half and after about 30 meetings with representatives of MWRiOP, the project of act regarding church taxes was prepared. It encompassed a part of proposals of clergy and, above all, a division of ordinary and extraordinary contributions ${ }^{48}$. Negotiations seemed to be in their ultimate phase. The concept included fees of a lower level than it was initially assumed, i.e. ordinary $-3 \%$ and extraordinary $-10 \%$ (maximum ten times a year) of direct taxes. It implemented quite complicated procedure of enacting and managing the fund similar to project that had been agreed with S. Grabski. Exemptions from fees for persons not obliged to pay state taxes were maintained as well ${ }^{49}$.

A legislative request placed by deputies from the Polish People's Party "Liberation" (PSL "Wyzwolenie") in June 1928 caused concern among the clergy. It pertained to revocation of obligations resulting from Austrian competition act, having constituted a basis of church taxes in the part of the II Republic of Poland, which had been ruled formerly by the Habsburgs. It has been assumed by the clerks from MWRiOP that to enact the project, and - later on - to extend the legislation to the whole country could have changed negotiation situation. However, the project was sent back to Administrative Commission and was lost there forever ${ }^{50}$. Furthermore, bishop from Lustk appealed that the competition act was not in compliance with concordat and addressed the MWRiOP indicating that: this argument - in my opinion - could be used during the meeting of the Commission, in order to fully eliminate the request from deputy Putek ${ }^{51}$.

Above all, negotiations led by bishop Szelążek were focused on wishes of clergy from the former Russian annexation. In fact, these environments seemed to have had more compromise attitude towards the property issues. As their material situation was much worse than the one of clergy from former Prussian and Austrian annexation, clergy from former Russian annexation aimed, fist of all, at reaching immediate agreement, even if having had to reign from some of their initial requests. However, church hierarchy from both, western and southern areas was not so much willing to concessions. As mentioned above, the project was actually finished in principle however primate August Hlond expostulated it. In January 1930, in his letter to bishop Szelążek, primate August Hlond declared objections towards the process of enacting church contributions by the Parishioners Assembly, norms regarding their height as well as excessive interference of authorities. The whole

48 Ibidem, sygn. 894, Letter from F.S. Potocki to A. Szelążek (project), 10-11.

49 AAN, MWRiOP, sygn. 893, Ustawa z dnia... 1929 r. o przymusowych składkach na potrzeby Kościoła katolickiego, 454-465; sygn. 894, Letter from F.S. Potocki to A. Szelążek (project), 10-11.

50 Druki Sejmu RP, 1928, no. 172, Sprawozdanie Stenograficzne z posiedzenia Sejmu Rzeczypospolitej Polskiej, no. 19, column 96.

${ }_{51}$ Original text: argument ten - mojem zdaniem, mógłby być wykorzystany na posiedzeniu Komisji, dla petnego wyeliminowania wniosku Putka. AAN, MWRiOP, sygn. 893, Letter from A. Szelążek to F.S. Potocki, 12.17.1928, 429. 
project, in his opinion, was "unrealistic and abortive"52. In addition, two other participants of the Pontifical Commission, bishops H. Przeździecki and S. Łukomski, expressed their determined opinion as follows: "current project was worse than any acts issued so far by annexation governments in this regard"53. In January 1930 bishop Szelążek informed his contemporary negotiation partner, F.S. Potocki: "I would not be able to overcome obstacles resulted from the opinion [given by A. Hlond], therefore for all further concordate issues, as well as for the current acts regarding contributions and cemeteries, it was necessary to gather the whole Commission" ${ }^{54}$. As of the beginning of February 1930, Prime Minister Kazimierz Bartel was addressed with information (from A. Kakowski and A. Hlond) that there was a plan to return to negotiations in a formula initiated in 1925, i.e. led by Pontifical Commission as a full (A. Szelążek, H. Przeździecki, S. Łukomski) ${ }^{55}$.

As it seems, since that moment, primate Hlond has been the one to take the initiative. Remarks to the project elaborated by A. Szelążek and F. Potocki - as it was explained in a letter written by bishop Przeździecki, had been prepared during the common meeting with cardinal Hlond - as advised by bishop from Lutsk on 30 January $1930^{56}$. In his replay to the aforementioned statements, minister Sławomir Czerwieński said: I had to only conclude that demands of the Pontifical Commission would completely change the hitherto content of the act in the agreed form... ${ }^{57}$. As a consequence, the discussion recommenced.

This time, however, negotiation process was official. On one side of the table was the aforementioned Pontifical Commission; while on the other side there was Governmental Commission-each consisting of three persons ${ }^{58}$. It is worth

52 AAN, MWRiOP, sygn. 894, Official letter from A. Hlond to A. Szelążek, 01.11.1930, pp. 19-22; ADŁ, ZAN, sygn. 260, Letter from A. Szelążek to S. Łukomski, 01.26.1930, non-paginated; J. Koterbski, „O tak zwanym Komitecie parafjalnym (kościelnym) w Małopolsce słów kilka”, Głos Narodu (February 2, 1929).

53 Original text: projekt obecny jest gorszy od wszelkich ustaw wydawanych przez rzady zaborcze $w$ tym przedmiocie. AAN, MWRiOP, sygn. 894, Letter from H. Przeździecki and S. Łukomski to A. Szelążek, 01.26.1930, 24-30.

${ }^{54}$ Original text: „z trudności, które ta opinia [A. Hlonda - przyp. K.Ch.] przynosi, ja sam wyjść nie zdołam, dlatego nie tylko do wszystkich następnych spraw konkordatowych [...] ale i do obecnie rozpatrywanych ustaw: o składkach i o cmentarzach niezbędne jest zawezwanie całej komisji"ADŁ, ZAN, sygn. 260, Letter from A. Szelążek to F.S. Potocki, 01.20.1930, non-paginated.

55 AAN, MWRiOP, sygn. 894, Letter from A. Szelążek to F. Potocki, 02.13.1930, 32.

56 Original text: jak wyjaśnia listownie biskup Przeździecki ułożone zostały na wspólnej naradzie z kardynałem Hlondem. AAN, MWRiOP, sygn. 894, Letter from A. Szelążek to F. Potocki, 01.30.1930, 23; sygn. 893, Uwagi Komisji Papieskiej do projektu o przymusowych składkach na potrzeby Kościoła katolickiego, 468-475.

57 Original text: muszę tylko skonstatować, że żądania Komisji Papieskiej zmieniaja do gruntu całą dotychczasowa treść projektowanej ustawy, tak jak została ona uzgodniona... AAN, MWRiOP, sygn. 894, Official letter from S. Czerwiński to A. Szelążek, 02.22.1930, 34.

58 A committee including: F.S. Potocki (MWRiOP), Jan Kanty Pieniążek (Legal Office of Presidium of the Council of Ministers), August Urban (Ministry of Treasury). 
to mention, that within the Pontifical Commission, there was a disagreement regarding assessment of both, the former project (the one prepared by bishop Szelążek) and the new proposals (based on comments given by A. Hlond). In bishop Szelążek's opinion, the project regarding obligatory contributions should be relatively moderate [...]; it shouldn't let the parties to stop negotiations ${ }^{59}$. Bishops Łukomski and Przeździecki, however, thought that it could be acceptable that negotiations on the act would be stopped rather than continued and approved in its current form ${ }^{60}$. Such disagreements took place only during internal meetings. While negotiating with the government, they have always presented homogenous attitude ${ }^{61}$. On 24 and 26 March and on 10 April 1930 they came to an agreement on the new version of the project of act based on the version dated 22 February 1929 and the proposal of $\mathrm{Church}^{62}$. The new project was a compromise. First of all, they have resigned from regulatory listing of detailed goals, which could have been financed from usual fees, as well as from extending a group of entities (legal persons) that could have been charged. Furthermore, they have revised the way of imposing fees, so that it has not been a decision neither of Parish Council (as requested by bishops) nor of Parishioners Assembly (a postulate from the government). In addition, they have launched an additional unit, having been appointed by the aforementioned gathering. An amount of usual fee was raised to 5\% whereas the level of extraordinary fee (obligatorily approved by the state authorities) has been left to the decision of adopting authority ${ }^{63}$. Finally, Pontifical Commission pledged to receive approval of the Holy Sea whereas governmental delegates stated that the Government would advocate and defend that project against the legislative bodies ${ }^{64}$.

During May 1930 arrived approval from Rome. Pope Pius XI advised, however, that the level of fees should be raised from $5 \%$ to $10 \%$. In addition, he proposed

59 Original text: projekt o składkach przymusowych winien być umiarkowany [...]; nie należy dopuszczać do zawieszenia pertraktacyj. ADŁ, ZAN, sygn. 260, Note: Działo się w Biurze Episkopatu Polskiego w Warszawie d. 14/II.1930 r., non-paginated.

${ }^{60}$ Original text: że raczej należy dopuścić do zawieszenia pertraktacji nad ta ustawa, niż dopuścić do przyjęcia projektu ustawy w obecnem jej brzmieniu. ADŁ, ZAN, sygn. 260, Note: Działo się w Biurze Episkopatu Polskiego w Warszawie d. 14/II.1930 r., non-paginated.

${ }^{61}$ ADŁ, ZAN, sygn. 260, Posiedzenie Komisji Papieskiej. Warsaw, 04.09.1930, non-paginated.

62 AAN, MWRiOP, sygn. 894, Letter from F. Potocki to H. Przeździecki, 04.04.1930, 74; Konferencja Panów Delegatów Rządu z Komisją Papieską w sprawie projektu ustawy o składkach kościelnych, 146; ADŁ, ZAN, sygn. 260, Konferencja Panów Przedstawicieli Rządu oraz Członków Komisji Papieskiej, 03.24.1930, non-paginated; Konferencja Panów Przedstawicieli Rządu oraz Członków Komisji Papieskiej, 03.26.1930, non-paginated; Konferencja Panów Delegatów Rządu z Komisją Papieską w sprawie projektu ustawy o składkach kościelnych, Warsaw, 04.14.1930, non-paginated.

${ }_{63}$ AAN, MWRiOP, sygn. 894, Projekt ustawy o składkach na rzecz Kościoła katolickiego, 147-154; Pro domo, 162-165.

${ }^{64}$ Original text: Rząd projekt ten wobec ciał ustawodawczych popierać i jego bronić będzie. ADŁ, ZAN, sygn. 260, Konferencja Panów Delegatów Rządu z Komisją papieską w sprawie projektu ustawy o składkach kościelnych. Warsaw, 40.10.1930, non-paginated. 
that the acceptance level of loans taken by the parish should be changed from the chef of the Ministry of Treasury and MWRiOP to the voivode ${ }^{65}$. The proposals were only partly accepted by government (the second demand). However, importance of the matter was underlined by the fact that at the end of June 1930 the meeting of governmental delegates with the Pontifical Commission was presided by the Prime Minister Walery Sławek ${ }^{66}$. During September 1930, they made slight technical amendments ${ }^{67}$.

Not only had there been difficulties while preparing the project, but it had had to be given under interministerial discussion. The compromise was so fragile, yet so important that minister Czerwiński pleaded in his covering letter to chefs of the resorts: I hereby advised on that case in order to focus your attention on the fact that it was crucial to remain the project of the text unchanged. Even a slight change could lead to new, probably long lasting negotiations [...] It was possible that some understatements and misunderstandings could be commented, clarified and supplemented in the executive order ${ }^{68}$.

Expectations of the chef of the Department of Denominations in MWRiOP have not been fulfilled. The first units which presented remarks were: Ministry of Defense, Ministry of Agriculture and Agrarian Reform, Ministry of Industry and Trade and Ministry of Public Works. An attempt to reach an agreement towards the differences, which took place at the end of January 1931, was only partly effective. A proposal of $\mathrm{F}$. Potocki to incorporate all remarks into executive order was not accepted by two of the aforementioned ministries (Ministry of Defense and Ministry of Agriculture and Agrarian Reform) ${ }^{69}$. In addition, in May 1931 the Ministry of Interior (MSW) declared that, except of a few detailed remarks, the act would have to be limited to the Roman Catholic Church. Such modification was justified by separatist activity of Uniate Church. In the letter mentioned

${ }^{65}$ ADE, ZAN, sygn. 260, Official letter from Office of Polish Episcopate to H. Przeździecki, 05.22.1930, non-paginated.

${ }^{66}$ Ibidem, Konferencja Komisji Papieskiej oraz Panów Delegatów Rządu dla wykonania Konkordatu. Warsaw, 06.13.1930, non-paginated; Protokół konferencji, odbytej w dniu 30 VI 1930 r. w Pałacu Rady Ministrów w sprawach związanych z wykonaniem Konkordatu, non-paginated.

67 AAN, MWRiOP, sygn. 894, Protokół z konferencji Komisji Papieskiej z Delegatami Rządu w Warszawie dnia 13 X 1930 r., 211-214; Protokół z konferencji Komisji Papieskiej z Delegatami Rządu w dniu 18 X 1930 r., 215; AAW, EP, sygn. A II 1.4 (2645), Konferencja Episkopatu Polski w Częstochowie w dniach 6-8 X 1931 r., 235; Sprawozdanie Komisji Papieskiej, 252.

68 Original text: Okoliczność tę podnoszę dlatego, żeby zwrócić uwagę Pana Ministra na konieczność pozostawienia tekstu projektu bez zmiany. Pozornie nawet nieistotna zmiana mogłaby za soba pociagnąć potrzebę nowych, niewiadomo jak długich, pertraktacyj [...] pewne niedomówienia i niejasności można będzie w rozporzadzeniu wykonawczem skomentować, wyjaśnić $i$ uzupetnić. AAN, MWRiOP, sygn. 894, Official letter of MWRiOP, 11.26.1930, 250-251.

69 AAN, MWRiOP, sygn. 894, Pro memoria w sprawie projektu ustawy o składkach kościelnych, 311-312; Protokół z konferencji w MWRiOP w sprawie uzgodnienia projektu ustawy o składkach kościelnych w dniu 26 I 1930 r., 352-355. 
above we could read that: with reference to the other rites of the Catholic Church, in particular the rite of the Greek Catholic Church, regulation of fees issue in accordance with the current project [...] would increase so considerably the material resources of these rites that their separatist activity, being of anti-state tendency, would strengthen so that it could constitute a considerable threaten to internal relationship within the State $e^{70}$. The final version of the project, agreed in November 1931, included proposals of the Ministry of Defense, the Ministry of Agriculture and Agrarian Reform and the Ministry of Internal Affairs (without limitation to Latin rite $)^{71}$. At the beginning of February 1932 the project was approved by the Council of Ministers and re-directed to Parliament. That government's proposal included, in its latest article, almost two-year moratorium which - together with the justification indicating that: due to material as well as formal matters, regulating that case was an immediate necessity - could have caused a cognitive dissonance ${ }^{72}$.

For the first time, Parialment verified the project (19 February 1932). The temperature of the debate remained relatively low as the project itself did not cause any particular interest, and finally was sent back to the Administrative Commission. The Nonpartisan Bloc of Cooperation with the Government (BBWR) as well as national and Christian Democratic environments advocated it. In fact, only the Polish Socialist Party (PPS) representative, Mieczysław Niedziałkowski, appealed that the project should be rejected due to economic and political reasons ("reaching an agreement between Brest case and the catholic doctrine of charity") ${ }^{73}$. At the beginning of March the discussion on the project of act started anew, this time however, with a higher level of interest. The content itself did not cause any interest, as previously, whereas the context of the whole situation turned out to be of high importance. Left-wing parties, as well as people's organizations, indicated on political aspect of the act. The deputy of the People's Party (SL) pointed out that the act would not come into force until the beginning of 1934 and stated

$70 \quad$ Original text: $w$ odniesieniu do pozostałych obrządków Kościoła katolickiego, w szczególności obrządku grecko-katolickiego, unormowanie sprawy składek według załaczonego projektu [...] zasiliłoby tak wydatnie zasoby materialne tych obrzadków, że uprawiana przez nich obecnie wytężona akcja separatystyczna o ogólnych tendencjach antypaństwowych wzmogła by się do tego stopnia, że mogłaby stanowić istotne niebezpieczeństwo dla wewnętrznych stosunków w Państwie. AAN, MWRiOP, sygn. 894, Official letter from MSW to MWRiOP, 05.05.1931, 375-380.

${ }^{71}$ AAN, MWRiOP, sygn. 894, Projekt ustawy o składkach na rzecz Kościoła katolickiego, 11.12.1931, 387-388.

72 Original text: ze względów rzeczowych, jak i formalnych prawodawcze uregulowanie tej dziedziny życia państwowego jest niecierpiąca zwłoki koniecznością. AAN, Presidium of the Council of Ministers (Prezydium Rady Ministrów, PRM), Protocols of the Council of Ministers (Protokoły Rady Ministrów, Prot. RM), sygn. 61, Protokół 4-go posiedzenia Rady Ministrów RP z dnia 8 II 1932 r., 340-341; Druki Sejmu RP 1932, no. 494.

${ }^{73}$ Original text: pogodzenie sprawy Brześcia z doktryna katolicka miłości bliźniego. Sprawozdanie Stenograficzne z posiedzenia Sejmu Rzeczypospolitej Polskiej 1932, no. 57, column 35-41. 
that: "the aforementioned act had remarkably political character. Sanation group, indicating on positive aspects of the project, aimed at having the clergy by their side, which was revealed by the representatives of the Nonpartisan Bloc of Cooperation with the Government (BBWR) during the commission"74. Summarizing, the majority in favor of the project was not threatened. Soon, on 17 March, the act was approved by Senate ${ }^{75}$ and was effective on the whole territory of Poland, excluding Silesian Voivodeship ${ }^{76}$.

Relatively distant statute of repose term enabled to work on preparation of the executive order. Nonetheless, interministerial settlements regarding the project lasted longer than initially expected. Preliminary version of act was prepared in November $1933^{77}$ whereas at the beginning of December, i.e. one month before the legislation passed on 17 March 1932 came into force, the content was sent for further verification of the Pontifical Commission. It was not until long (i.e. at the beginning of February 1934), that the Pontifical Commission sent back a number of remarks. Objections concerned the same issues that had already been pointed out during negotiations. There were, in particular, the matters of enacting, administrating and control of contribution fund as well as a role of Parishioners Assem$\mathrm{bly}^{78}$. Bishops gathered on Polish Plenary Episcopal Conference on 20 February 1934 supported opinion given by the Pontifical Commission; they stated that: "the governmental project was not acceptable" 79 . MWRiOP administrated the case. They initially planned to organize a common meeting with representatives of the Church that was advised to bishop Przeździecki. His attitude towards the idea turned out to be positive, he even attempted to organize such meeting however his attempts did not bring any positive outcome $e^{80}$. First of all, governmental authorities decided to reach an agreement between distant attitudes of the particular ministries and, afterwards, they aimed at reaching an agreement within the Pontifical Commission. At the end of September 1934 a new version of the directive was ready ${ }^{81}$. And for the next time it was predictable that the

74 Original text: przedłożona ustawa ma wybitnie charakter polityczny. Obóz sanacyjny droga rzekomych dobrodziejstw chciałby pozyskać kler dla swoich celów politycznych, co ujawnili przedstawiciele B.B. na komisji. Sprawozdanie Stenograficzne z posiedzenia Sejmu Rzeczypospolitej Polskiej 1932, no. 65, column 39-64.

75 Sprawozdanie Stenograficzne z posiedzenia Senatu Rzeczypospolitej Polskiej 1932, no. 38, column 34-52.

76 DURP 1932, no 35, pos. 358; „Składki na rzecz Kościoła katolickiego”, Gazeta Polska 339 (1933).

77 AAN, MWRiOP, sygn. 897, Official letter from MWRiOP to MSW, 12.02.1933, 102.

78 Ibidem, Uwagi do rozporządzenia MWRiOP o składkach kościelnych, 196-200.

79 AAW, EP, sygn. A II 1.3 (2644), Konferencja Plenarna Episkopatu Polski, Warsaw, 02.20.1934, 195 .

80 AAN, MWRiOP, sygn. 897, Official letter from Pontifical Commission to MWRiOP, 08.23.1934, 328 .

81 AAN, MWRiOP, sygn. 896, Official letter from MWRiOP do Office of Polish Episcopate, 12.16.1934, 85-86; AAN, MWRiOP, sygn. 897, Protokół z konferencji międzyministerialnej 
tedious negotiations would take place. It was planned that the scope of cooperation, as well as representation of both parties, would be precisely indicated.

And again, matters took longer than expected. Kielce case, as well as reprivation of budgetary grants for diocesans in Kielce and suspension - by the government lead by Walery Slawek - of the activity of the Pontifical Commission, had negative impact on relationship between the government and the church hierarchy ${ }^{82}$. In the meantime, in October 1935, primate Hlond issued a pastoral epistle in which he dissented from mandatory church contributions. "I hereby abolish mandatory fees given under duress of a law. There would be no taxes" ${ }^{\text {". At }}$ the same time they launched a new way of managing property issues of parishes in diocese of Poznan ${ }^{84}$. Surprisingly, the government approved the aforementioned decision with the aim of achieving good relationship with the primate ${ }^{85}$. Therefore, prompt action has been undertaken as it has been written: "the MSZ [Ministry of Foreign Affairs] had taken care of principles of the project of executive order which had redirected the case to more realistic way of proceeding" ${ }^{36}$. The project was supposed to be led by minister Wojciech Świętosławski whereas from the Church site primate Hlond led it ${ }^{87}$. Representatives of both sides, after long-lasting and time-consuming works, reached an agreement with reference to the content of the directive ${ }^{88}$. This was a considerable concessions from the Church site which, in 1938 was commented by the director of the Department of Denominations of MWRiOP, Henryk Dunin-Borkowski as follows: it was a great success

w MWRiOP z dnia 29 i 31 X 1934 r. w sprawie projektu rozporządzenia wykonawczego do ustawy z dnia 17 III 1932 r. o składkach na rzecz Kościoła katolickiego, 258-271; Pro memoria, 280-282.

82 „O harmonijną współpracę państwa i kościoła”, Warszawski Dziennik Narodowy (November 26, 1935).

83 Original text: Znoszę zatem świadczenia przymusowe składane pod przymusem prawa. Nie będzie podatków. August Hlond, Z Prymasowskiej Stolicy. Listy pasterskie (Poznań: Naczelny Instytut Akcji Katolickiej, 1936), 176; „Ks. prymas Hlond zrezygnował z pobierania podatku kościelnego”, Ilustrowany Kurier Codzienny, November 14, 1935; „Światłe zarządzenie Ks. Prymasa Hlonda w sprawie podatku kościelnego", Polska Zachodnia (December 3, 1935).

${ }_{84}$ Edmund Nowicki, Kościelne prawo majątkowe (Poznań: Drukarnia św. Wojciecha, 1936), 123-167, 270; „O kościelnych sprawach majątkowych”, Kurier Warszawski (November 12, 1935).

85 Wiesław Mysłek, Kościół katolicki w Polsce w latach 1918-1939 (Warszawa: Książka i Wiedza, 1966), 132-133.

${ }^{86}$ Original text: MSZ zajęło się kwestia ustalenia zasad do projektowanego rozporządzenia wykonawczego i skierowało tę sprawę na bardziej realne tory.

87 AAN, MWRiOP, sygn. 897, Notatka $\mathrm{z}$ konferencji międzyministerialnej, 11.10.1938, 656.

88 Ibidem, Protokół konferencji z 23 VI pomiędzy del. Stolicy Apostolskiej ks. kard. A. Hlondem a del. Rządu RP min. WRiOP W. Świętosławskim, 571-573; Zasady rozporządzenia, które ma być wydane na podstawie art. 16 ustawy z dnia 17 III 1932 r. o składkach kościelnych na rzecz Kościoła katolickiego, 576-577; Analiza uwag ks. kard. Hlonda do przesłanych dnia 27 VII 1936 r. zasad rozporządzenia do ustawy o składkach kościelnych, 02.21.1937, 583-587; Projekt protokołu z 5-ej konferencji z kard. Hlondem, 11.02.1937, 620-622; Pro memoria, 623; Letter from W. Dymek to F.S. Potocki, $04.05 .1938,713-715$. 
of assistants of Mr. Świętosławski ${ }^{89}$. The comment referenced to the main case that was a scope of interference of the government into the way of dimension and collecting of church fees. From the four ministries, which took part in the process of negotiations: the Ministry of Justice, the Ministry of Treasury, the MWRiOP and the MSW unexpectedly the last one argued against the agreed decisions. An attempt to reach an agreement, taken in November 1938, was not successful ${ }^{90}$. Due to implacable attitude of MSW, there was a risk that the pluriennale work of several governments would be wasted. Therefore, at the end of November, a chef within the Department of Denominations appealed for support to a chef of the ministry: it would not be in accordance with our expectations that the negotiations would be cancelled due to one postulate of church authorities, especially that the postulate was of no substantive importance. Hence, MWRiOP hereby asks the Minister to directly address the Prime Minister, as MSW, in order to achieve a change of approach towards the aforementioned case ${ }^{91}$. A proclamation turned out to be effective as in December 1938 the parties managed to close the case. As it was written then: justice was done. Prerequisites included in article 16 of the act mentioned above, principles of the directive, will be agreed with the suitable ecclesiastical authority. Thus, minister Swiętosławski hereby declared that competent state authorities would issue the discussed executive order ${ }^{92}$. Negotiations have been finished however before the outburst of the war, the directive has not been issued and the act on contributions has remained a "dead letter".

\section{Church contributions - an amount and collection}

An amount of tax, or parish contribution, depended on current situation of the particular parish as well as on salary system in the given region of the country. In time of the Second Republic of Poland both, state authorities as well as

89 Original text: asystenci Pana Świętosławskiego uzyskali duży sukces. AAN, MWRiOP, sygn. 897, Notatka z konferencji międzyministerialnej z dn. 10 XI 1938, 657.

${ }_{90}$ Ibidem, sygn. 897, Official letter from MSW to MWRiOP, 06.07.1937, 616-617; Official letter from MSW to MWRiOP, 11.26.1938, 637; Protokół z konferencji międzyministerialnej prawniczej z dnia 9 VI 1937 r. w MWRiOP, 688-689.

${ }_{91}$ Original text: byłoby to rzecza ze wszechmiar niepożądana, gdyby doszło do zerwania pertraktacyj dla tego jednego postulatu władz kościelnych nieposiadającego znaczenia merytorycznego. Departament Wyznań prosi Pana Ministra o bezpośrednie porozumienie się z Premierem jako MSW celem uzyskania zmiany stanowiska, zajętego w powyższej sprawie przez jego resort. Ibidem, Official letter of MWRiOP, 11.19.1938, 647-660.

92 Original text: iż stało się zadość wymogom zawartym $w$ art. 16 wyżej wymienionej ustawy, „iż zasady tego rozporzq̨dzenia będa uzgodnione $z$ właściwa władzq duchowną. W związku $z$ tym Minister Świętosławski oświadcza, iż kompetentne władze państwowe przystapia do wydania omawianego rozporządzenia wykonawczego. Ibidem, Protokół konferencji z XII 1938 r. pomiędzy del. Rządu RP min. WRiOP W. Świętosławskim a del. Stolicy Apostolskiej ks. kard. A. Hlondem, 752-757. 
ecclesiastical authorities were not in disposal of the data that could indicate a precise amount of tax. An attempt to verify the issue has been taken after signing the concordat. They searched for information in the former Prussian annexation as the situation there seemed to have been the most clarified however the outcome was not satisfactory. In November 1927 central authorities in Warsaw were informed as follows: I managed to find out from people familiar with former relations that church taxes had not been equal. In some parishes no renovations had taken place for a number of years so the taxes had not been collected. In the other parishes, however, in one year the taxes had been higher whereas in the other one lower which had depended on the amount of construction costs ${ }^{93}$. Moreover, the ministries, looking for "at least approximate data", have not been supported by the Polish primate, whom they had asked for help, indicating that receipt of such information would have been long-lasting and it would have $\operatorname{cost}_{\text {much }}{ }^{94}$. At the end of 1927 Pomeranian voivode informed MWRiOP: I was not in a disposal of the data, based on which I would be able to calculate even an approximate amount of a church fee to have been imposed on catholic population, [...] therefore I had addressed Episcopal authorities for explanation ${ }^{95}$.

On the contrary, an answer from Silesian voivode was been relatively detailed. An amount of the church tax - as he stated - was not "too burdensome" for both, clerks and teachers: as an example I give an average clerk of VII level, having a monthly salary in amount of $300 \mathrm{zl}[. .$.$] in the given example a church tax$ amounts to $3 \mathrm{zl}$ per month. Of course, in case of higher salary the tax would be relatively higher. Based on the above, the burden is not so severe to justify a demand of a statutory exemption ${ }^{96}$.

93 Original text: Zdołałem tylko dowiedzieć się od osób obznajomionych z dawniejszymi stosunkami, że podatki kościelne byly nierówne. W niektórych parafjach nie przeprowadzano przez szereg lat remontów, skutkiem czego też nie pobierano podatków. W innych znów w jednym roku pobierano większe podatki, w następnym zaś mniejsze, zależnie od wysokości kosztów budowlanych. AAN, MWRiOP, sygn. 893, Letter of S. Dąbrowski, 11.26.1927, 404-405.

${ }_{94}$ AAN, MWRiOP, sygn. 893, k. 354, Letter to J.K. Noryśkiewicz, 11.18.1927; Official letter from Chancellery of the Primate of Poland to MWRiOP, 11.24.1927, 401. Based on these information, calculations made by J. Wisłocki, who did not take into consideration a local context of the issue, are not fully justified. Jerzy Wisłocki, Uposażenie Kościoła katolickiego i duchowieństwa katolickiego w Polsce 1918-1939 (Poznań: Wydawnictwo Naukowe Uniwersytetu im. A. Mickiewicza, 1981), 198.

95 Original text: nie posiadam danych, na podstawie których mógłbym choćby w przybliżeniu obliczyć wysokość obciążenia ludności katolickiej podatkami kościelnym [...] w tej sprawie zwróciłem się przeto do władzy biskupiej o wyjaśnienie. AAN, MWRiOP, sygn, 892, Official letter from Pomeranian Voivodeship Office to MWRiOP, 12.03.1927, 63.

96 Original text: $z a$ przykład biorę urzędnika średniego w VIII stopniu stużbowym, pobierajacego 300 zł uposażenia miesięcznego [...] w niniejszym wypadku wynosi podatek kościelny 3 zł miesięcznie. Oczywista przy wyższych poborach stosunkowo więcej. Ciężar ten zatem nie jest tak dotkliwy aby uzasadniat żądanie ustawowego zwolnienia. AAN, MWRiOP, sygn 892, Official letter from Silesian Voivodeship Office to MWRiOP, 06.10.1928, 96. 
Certainly, in time of the Second Republic of Poland, if necessary, church taxes (contributions) were imposed. Collection, however, constituted a real problem. As mentioned above since 1925 in the former Russian annexation there has been an „ex lex" state that has disabled actual execution of church taxes collection. In Prussian annexation where the system of patronage existed and parishes were usually at disposal of suitable salaries, taxes were imposed relatively infrequently and, if so, in insignificant amount. Of course, there has been an exception; in case of construction of new churches or other parish buildings: Usual income from church fee, fee for church places as well as other voluntary donations, were sufficient to cover ordinary annual parish expenses, so only from time to time there was a necessity to collect church fee for some considerable construction expense. However, even in such cases the tax was not considerable as almost all parishes in former Prussian annexation had a patron ${ }^{97}$. In Pomeranian Voivodeship the situation was similar: "church fees were imposed only exceptionally"

As soon as an act on church taxes has been enacted, problems of collecting fees in other regions of Poland revealed. At the beginning of 1936 Lviv voivode advised as follows: there is a critical situation, especially that there was no hope when this state "ex lex" would be terminated ${ }^{99}$. Fees could have been enacted, however there was no legal background for tax authorities to execute them ${ }^{100}$. Incomes of parishes were dependent exclusively on good will of parishioners, which, in case of long-lasting economic crisis, considerably decreased propensity of donations. The aforementioned proclamation of archbishop Hlond, abolishing mandatory fees in his direct diocese, constituted an additional sign of protest towards the existing situation.

As a conclusion, it could be stated that the amount of taxes has never been fully determined and, as so, has never been known to state authorities, as well as ecclesiastical authorities. Far before the First World War Władysław Grabski wrote: it has not been possible to determine the amount of parish expenses [...]

${ }_{97}$ Original text: Zwykle dochody ze składki kościelnej, z opłaty za miejsca kościelne i z innych dobrowolnych datków wystarczaja na pokrycie zwyczajnych rocznych wydatków parafjalnych, tak że tylko od czasu do czasu zachodzi potrzeba pobierania podatku kościelnego na jakiś znaczniejszy wydatek budowlany. Także i w takich razach podatek kościelny jest zwykle nieznaczny, ponieważ prawie wszystkie parafje w b. zab. pruskim posiadaja patrona. AAN, MWRiOP, sygn. 893, Pokrywanie potrzeb kościelnych w katolickich gminach kościelnych w b. zaborze pruskim, 66; sygn. 892, Official letter of Voivodeship Office in Poznan, 03.22.1930, 135-139; AAN, PRM, Numerical Documents (Akta numeryczne), sygn. 9543/20, Official letter from MWRiOP do Marshal of the Sejmu, 05.17.1920, 7.

98 AAN, MWRiOP, sygn. 892, Official letter from Pomeranian Voivodeship Office to MWRiOP, 05.31.1928, 99.

99 Original text: wytworzyła się więc sytuacja krytyczna, tembardziej, że niema nadzieji kiedy ten stan "ex lex" będzie usunięty. AAN, MWRiOP, sygn. 899, Official letter from Voivodeship Office in Lviv to MWRiOP, 01.14.1936, 228.

100 AAN, MWRiOP, sygn. 899, Official letter from Voivodeship Office in Krakow to MWRiOP, 09.11.1936, 237. 
a considerable part of expenses has been covered by contributions as well as voluntary donations based on acts not given to governmental consent in order to avoid harassment and costs which would have been generated in the process of approval ${ }^{101}$.

\section{Karol Chylak}

\section{The Church Rates (Contributions) in Parishes in the Second Republic of Poland}

\section{Summary}

The Church rate, church fee, church contribution. In the period of the Second Republic of Poland the state's and the ecclesiastical authorities used these terms in order to determine financial weights voluntarily adopted by parish institutions although obligatorily paid by faithful of the Roman Catholic Church. They were established during the Partition: in the Kingdom of Poland (Congress Poland) in 1817, in the Austrian Partition in 1866 and in the Prussian Partition in 1905.

Having concluded a concordat by Poland and the Holy See (1925), a regulatory process of this complicated issue started. It took until 1930 for the parties to complete the first phase of negotiations. The arrangements brought about passing the Church rates' law by the Polish Parliament (1932). In the second stage, there were discussions aiming at implementation of a detailed regulation of parish contributions through administrative regulation. These discussions lasted until December 1938. In spite of reaching an agreement, the state's authorities didn't publish the aforementioned law by the outbreak of the Second World War. As a result of that, the law has never come into force. Thus, compulsory parish contributions - having over a century of history - have been permanently liquidated.

101 Original text: ustanowić jednak wysokości wydatków parafialnych nie sposób [...] znaczna część wydatków pokrywa się składkami i dobrowolnemi ofiarami na mocy uchwał, nie podawanych do zatwierdzenia rządowego dla uniknięcia szykan i kosztów, jakich zatwierdzenie tych uchwat wymaga. Grabski, Ciężary samorządu, 75. 